\title{
Overcoming the hurdles and realizing the benefits
}

$\mathbf{T}$ he idea of librarians taking a sabbatical might seem odd to some, but there are a number of important reasons why librarians, if eligible, should apply and take one. In the library literature, the reasons for sabbaticals include an antidote to stress and burnout, helping the organization move forward, and serving to provide equivalency to teaching faculty, but only a relatively small percentage of eligible librarians actually take their sabbaticals. ${ }^{1}$

An overlooked reason for academic librarians to take sabbaticals is found in the irony that although we support faculty and students as they complete complex research projects, librarians often do not have personal experience with such projects themselves. A better understanding of managing a research project (even a relatively small, contained one) can provide insights into the workflow and problems that teaching faculty counterparts might encounter. Those insights can assist us in creating library services that better support our patrons as they move through their research projects.

It is important to acknowledge though that not all academic librarians work at institutions where they are eligible for a sabbatical or if eligible, not supported. Nevertheless, some kind of abbreviated research leave for which one can apply might be available. Although reasons listed in the literature for not taking sabbatical include lack of funding and the concomitant staffing shortages, from my own institutional experience, I would argue that fear of the unknown is also a significant barrier. This article is intended to pull back the curtain of unknowns surrounding librarian sabbaticals and to suggest how a sabbatical could result in better library research support services.

\section{Logistics}

I had been contemplating the idea of a sabbatical for some time, but several things had prevented me from applying. When I was first eligible, I had small children still at home. This is not conducive to a productive sabbatical. Then, I struggled to find a project that was both interesting and manageable in the six-month time frame. This is not an uncommon problem as Tamara Weintraub notes. ${ }^{2}$

At my institution, typical sabbaticals come in two flavors, six months at full pay or one year at half pay. The latter option was not economically feasible, so I needed to consider projects that could be completed largely in the six-month time frame. At my institution, applications are due about eight months prior to the start of the sabbatical, so I did have to plan ahead.

The application consisted of a short twopage document that included the following: a personal statement, a project description, a statement indicating how I would go about completing the project, a timeline, what I would produce from the sabbatical, and the outcome for the library.

Anna Marie Johnson is head of research assistance and instruction at the University of Louisville's Ekstrom Library, email: annamarie@louisville.edu

(c) 2018 Anna Marie Johnson 


\section{Project planning}

Coming up with a project was the most challenging part. Six months is a long time to contemplate working on one project. Our work, in my experience, is often fractured. Often I'm working on 10 to 15 quite different projects or tasks at once, so the idea of doing one for six months or more can be daunting to consider. What I finally settled on was a review of the literature of reference librarianship and interviews with other heads of reference to try to understand and plan for the future of my department. The end result of my research was a report to my dean and my department along with an article. It helped me to realize that the project was mine and that the outcome would be mine, too-no one else had any concrete expectations of what the report and the article might look like. I had the freedom to craft those into whatever shape I felt they should take. About midway through the project, the flow of the report emerged.

Because I was interviewing people and in-

\section{Reasons why librarians should take a sabbatical}

- Refreshes one's perspective; combats burnout, and provides a "reboot" to your day-to-day work

- Provides you with a more typical faculty experience; helps you understand what faculty do in a deeper way.

- The skills of managing one's own project, keeping to the timelines, and producing something are always good to hone.

Things to consider

- Obviously colleagues have to take on extra work. Be sure to thank them appropriately!

- Clearly, a sabbatical is not a long, paid vacation. If managed correctly, it can provide valuable insight into the research process.

- Planning ahead is vital. tended to publish the results of those interviews, I completed the institutional review board process at my institution. This was time consuming, but also quite useful. It provided insight into the process that many faculty experience, and it now allows me to guide other librarians and faculty through that same process. It does also require some planning ahead, as completing the training modules took approximately five or six hours, and then the application itself required another six or seven hours plus the waiting time to receive a decision, revising my application, and then waiting for the final approval.

Since I wanted to actually visit some libraries, I applied for a professional development grant through my state library association to pay for the travel. I knew from a previous experience of being on the committee that there were usually very few applications, but I was still excited to receive a $\$ 500$ stipend to cover my travel to two other states to talk with librarians face-toface. Many library associations and institutions will likely have money to support conference attendance, travel, postage, or other costs associated with a research project. These grants often do not require a lengthy application process, and they are usually reasonably easy to obtain.

\section{My life on sabbatical}

Once the planning was complete, it was time to actually take the sabbatical. For the first part of my sabbatical, my family and I traveled. This is not to imply that a sabbatical is just a long vacation by any means, but I found that by inserting the vacation in between my last day "at work" in the office and the start of my sabbatical, I was able to have the mental break I needed to wipe the slate clean, so to speak. It also prevented my colleagues from contacting me and drawing me back into the day-to-day.

Once I started my work, I found that I was most productive in the morning. At the end of the previous workday, I would create a brief plan for the next day so that I could simply jump in. I set up a table in the living room to hold all of my papers and books, and I often printed articles so I could sit outside and read when it was nice. Yes, I used more paper, but it was better for my mental health. 
Each day, I would spend several hours reading, often through lunch. Afterward, I usually took the dog for a walk, which allowed my brain to sift through the day's reading and make connections. In the afternoon, I tried to keep up with ensuring that my notes were in my EndNote library and that I followed up on other citations I had identified or I worked on transcribing interviews that I had done in the previous weeks.

I also kept a diary of my work. At first I tried to use a blog, but that seemed awkward, especially since it was only for me. I felt that full-on blogging of the sabbatical as I went would be distracting and take away from my focus, so, in the end, I simply had a Word document where I recorded briefly what I had done that day and a tally of the hours I had worked. It was important to me that I be able to demonstrate the time and effort I had put into my final project.

Email was probably the trickiest thing to manage. I tried to create a rule that emails addressed only to me (as opposed to a group of people) went to a special folder that I looked at regularly. Many of my colleagues were kind enough to remove me from their distribution lists which also cut down on the emails I saw. In the end, though, I still had to spend time each week at least scanning the emails to see if faculty or students had missed my away message and needed a response (this happened at least two times over the course of my time away).

I discovered that although I could use a virtual private network (VPN) connection into my office computer, my home computer was quite slow. It worked, but I had to switch out of the VPN if I wanted to listen to audio or watch video. This made for a clunky and cumbersome process. I should have tested this ahead of time, and either planned for it, or perhaps invested in a new computer.

Transcribing the interviews took a long time. I should have spoken to colleagues who were doing this at the time to learn more about the process. I tried software, but it was really not all that much faster, and it was quite expensive.

I had to do the phone interviews from my office, since I don't have a landline and my cell phone was not adequate to the task. While this didn't present a huge problem, I might have been able to find another solution if I had thought it through ahead of time.

\section{While I was away}

Next time, I probably would try taking a January to June sabbatical. Coming back at a busy time in January was somewhat overwhelming. Speaking of busy times, yes, your colleagues will have more work to do as a result of you being away. There is simply no way around it. I tried to wait until the department was fully staffed, but, despite my best intentions, two librarians (out of a department of eight) left while I was gone. I am very fortunate to have colleagues who saw the value of my sabbatical for our department, and who were able to step up and take on more.

The reality is that academia, as a general rule, moves slowly, and there are some tasks that can be postponed without too much loss of momentum. I found that a little thank you, such as a surprise box of donuts, goes a long way toward keeping everyone's spirits up.

\section{Returning from sabbatical}

When January came, I felt ready to return. I was proud of the 47-page report that I was turning in to my dean, and while my article wasn't in draft form quite yet, I felt I could take the literature review from my report and fairly easily turn it into an article, which I subsequently did. ${ }^{3}$ The most difficult part of coming back was trying to carve out time to continue to do what Cal Newport calls deep work, work that requires sustained concentration. ${ }^{4} \mathrm{I}$ came back with a renewed commitment to not waste my time (or any of my colleagues) with meetings that do not have a productive outcome and also to write emails that were clearer and responded directly to the question at hand or which were directive as to the response I desired. I am still in the process of blocking email and creating rules for emails that don't require my immediate attention.

One of the outcomes of my sabbatical research is that I am encouraging the librarians in my department to get out more and speak

(continues on page 624) 
in Europe, 1948-1950. Provides original documentation for the Records of the US Special Representative in Europe during 1948-50. The Economic Cooperation Administration oversaw the Marshall Plan's technical and economic aspects of the detailed document. Access: https://www.archives.gov/publications/record/1998/09/marshall-plan.html.

- Truman and the Marshall Plan. From the Harry S. Truman Presidential Library, this site furnishes direct correspondence documentation from 1946 to 1954. The correspondence included individuals, such as Charles Kindleberger and Mike Mansfield. Access: https://www.trumanlibrary. org/whistlestop/study_collections/marshall/ large/index.php.

\section{Conclusion}

The aim of this article is to provide unique user population groups with primary documentation for issues pertaining to the origins of the Cold War. Each section provided a unique insight into natural security, foreign policy, and military proceedings. The sections provide users with a variety of primary source material, including original documentation, oral histories, and many other forms of topical correspondence for future investigation.

\section{Notes}

1. The Harvard Project on the Soviet Social System Online-Harvard College Library," Harvard Project on Soviet Social System Online, accessed June 8, 2018, http:// hcl.harvard.edu/collections/hpsss/.

2. "Cold War Intelligence," BrillOnline Primary Sources, accessed June 08, 2018, http:// primarysources.brillonline.com/browse /cold-war-intelligence. 2

\section{("Librarian sabbaticals," continues from page 609)}

with their faculty about their teaching and research face-to-face when they can. For my part, I feel much more confident now asking a faculty counterpart to describe their research and to point out where the library could perhaps be useful. I recognize from my own experience where I struggled and how little things like having articles I needed available and organized was a huge help when it came to getting started.

\section{Conclusion}

For me, a sabbatical provided a much-needed midcareer pause that I found refreshing and rejuvenating. In addition, the project I completed will have long-lasting benefits for my library and my department. If you are still unconvinced, a good overview of the types of projects, additional advice from those who have taken sabbaticals, and other benefits, is "Exploring the Sabbatical and Other Leave as a Means of Energizing a Career" by Marlis Hubbard. ${ }^{5}$ If you are fortunate enough to be at an institution that supports and encourages librarians to take sabbatical, what are you waiting for?

\section{Notes}

1. Molly R. Flaspohler, "Librarian Sabbatical Leaves: Do We Need to Get out More?," Journal of Academic Librarianship 35, no. 2 (2009): 152-61 152-61; David Fox, "The Scholarship of Canadian Research University Librarians," Partnership: The Canadian Journal of Library $\&$ Information Practice $\&$ Research 2, no. 2, https://journal.lib.uoguelph. ca/index.php/perj/article/view/305/562\# .Wk-KA7BG270.

2. Tamara Weintraub, "Sabbatical in Paradise," Community \& Junior College Libraries 14, no. 3 (2008): 153-60 153-60.

3. Anna Marie Johnson, "Connections, Conversations, and Visibility: How the Work of Academic Reference and Liaison Librarians is Evolving," Reference and User Services Quarterly, [accepted].

4. Cal Newport, Deep Work: Rules for Focused Success in a Distracted World, First edition. ed. (New York: Grand Central Publishing).

5. Marlis Hubbard, "Exploring the Sabbatical or Other Leave as a Means of Energizing a Career," Library Trends 50, no. 4 (2002): 603-13. z2 